\title{
PRIMARY EDUCATION IN TABRIZ CITY DURING THE GAJARS PERIOD
}

\author{
НАЧАЛЬНОЕ ОБРАЗОВАНИЕ В ТЕБРИЗЕ В ПЕРИОД ГАДЖАРОВ \\ KAÇARLAR DÖNEMINDE TEBRIZ ŞEHRINDE İLKÖĞRETIM \\ Ilhama MAMMADOVA GULBALA \\ ORCID:0000-0002-6884-4678
}

İnstitute of Archaeology and Ethnograpy of ANAS, Doctor of Historical Sciences

\begin{abstract}
Education was of religious character with schools and madrasahs in Tabriz, as in all Muslim cities during the Middle Ages and was based on the methodology of religious tenets. This type of education system dates back to the early years of Islam and was yet ongoing during its research period. Schools provided primary spiritual education, whereas madrasahs provided high religious education. The first madrasah in Iran was established in Tabriz. Literacy was taught and basic rules and regulations were applied at schools. They operated mainly within the mosques and the classes were held in zaviya (madrasah) and cell. The mosques performed numerous functions. They were not only places of worship (practicing namaz, listening to preaching, etc.), but also the place where Sharia laws are studied and propagated; holy war and peace declared; spoils of war are distributed; letters sent to the authorities; funerals held and where the other work was done.
\end{abstract}

Keywords: Tabriz, education, school, textbook, teaching

\section{РЕЗЮМЕ}

В средние века, как и во всех мусульманских городах, образование в Тебризе, включая школы и медресе, было религиозным по своей природе и основывалось на методологии религиозных догматов или верований. Этот тип системы образования восходит к раннему периоду ислама и все еще находится в зачаточном состоянии. Школы давали начальное духовное образование, а медресе - высшее религиозное образование. В школах учили грамоте и применяли элементарные правила. В основном они действовали при мечетях, а занятия проводились в Завии и шабистане. Мечети выполняли множество функций. Это были не только места поклонения (молитва, слушание религиозных проповедей и т. д.), но также место, где изучались и распространялись законы шариата, провозглашался джихад (священная война) и мир, распределялись военные трофеи, отправлялись письма в высшие круги, и проводились похороны - и где выполнялись другие работы.

Ключевые слова: Тебриз, образование, школа, учебник, обучение.

\section{ÖZET}

Orta Çağ boyunca, tüm Müslüman şehirlerde olduğu gibi, Tebriz'de de okullar (okulhane) ve medreseler de dahil olmak üzere eğitim, doğası gereği diniydi ve dogma metodolojisine dayanıyordu. Bu tür bir eğitim sistemi, İslam'ın ilk günlerine kadar uzanır ve araştırma sırasında da hala devam etmekteydi. Okullar ilk manevi eğitim ve medreseler yüksek din eğitimi vermekteydi. Okullarda okuryazarlık öğretiliyordu ve temel kurallar uygulanıyordu. Okullar ağırlıklı olarak camilerde faaliyet gösteriyorlardı ve dersler zaviye ve şabistan'da yapıllyordu. Camiler birçok işlevi yerine getirirdi. Bunlar sadece ibadet yerleri (namaz kılmak, vaaz dinlemek vb.) değil, aynı zamanda şeriatın incelenip yayıldığı, cihat ve barışın ilan edildiği, savaş ganimetlerinin dağıtıldığı, yüksek makamlara mektupların gönderildiği, ölülerin cesetlerinin yerden kaldırıldığı ve diğer işlerin yapıldığı yerdi.

Anahtar kelimeler: Tebriz, eğitim, okul, ders kitabı, öğretim.

\section{EDUCATION}

Tabriz was one of the cultural centers of not only Azerbaijan and Iran, but probably also the Middle East in the XIV-XV centuries. A lot of schools and madrasahs functioned and academic personnel were trained there [Onullahi. 1976, 38].

Received 22 Dctaber 20Z1; Received in revised form 27 November 20Z1; Accepted 30 November 20Z1;

Available online 28 December 2021;

dai: I0.4629I//CONTECHvol5iss4pplo-23 


\section{ICONTECH INTERNATIONAL JOURNAL OF SURVEYS, ENGINEERING, TECHNOLOGY}

Most schools were located in the center of the district, in the shops, in the private houses of akhunds or in the houses given them free of charge, as well as in special places at the disposal of school staff besides mosques in the 19th and early 20th centuries [Egbal Gasemipuya. 1377, 45]. The akhund, who was the head of the school did not follow a single rule during teaching and during the admission of students. According to the informers, there were very few people inclined to read in the past. Supposedly, it was due to the children's desire to continue their inherited professions and the difficulty of teaching. Moreover the children of nobles, generally, those of wealthy families were involved in teaching.

According to the sources, schools can be grouped as follows:

- general schools, private schools and schools where classes are taught by women (female akhund or female mullah).

General schools functioned in the mosques, private apartments, shops, and rented rooms as was mentioned above. It was easy and inexpensive to open such schools. Because the school did not have a permanent building. Therefore, since the classes were held mainly in the mosque, there was no need for other teaching resources other than the teacher's desk and cushion.

Most places for teaching were unhygienic with the exception of mosques. Heat in the classrooms was provided by a stove on the wall, while a charcoal brazier was used in many places. The classes were held in the basement of the building during the hottest days of summer.

There were not modern desks, chairs and blackboards in the classrooms. Mats, felt, rugs, or carpets were placed on the floor for the students who sat on their knee there. Everyone brought a cushion from their houses to sit comfortably. Nimdars (cushion, little mattress) were lined up along the walls of the room and the students sat faced to the wall. The students would have to sit in the middle of the room if there were many of them. The children had to sit for hours, which caused inconvenience to them. The akhund, who led the lesson, could sit at the top and see everyone and control the class. He had a stick made of oleaster tree in his hand to punish lazy and naughty children. The 'falagga' (فلى جوب) machine (intended for reproaching the children) was also used for this purpose.

The children took turns for sitting in front of the akhund and repeated what he said during the lesson. The student took his place upon completing and was replaced by another classmate. Each student had to memorize the lesson after taking a seat and retell the lesson to the akhund in the afternoon. The lesson lasted from sunrise to sunset and during this time children were not allowed to leave the school. They could only leave the class for one hour of lunch. The children were excluded from games and fun due to these wearisome rules. Memorizing the texts taught without knowing the meaning reduced the interest in the school. The students brought book, notebook, pencil case, ink and small black board there. It is known from the memories of the elderly residents that, the children used to take food to school and had lunch during breaks.

Students started their classes at different times and at different ages. Those who started classes on the same day were called "classmates". Elder and more skilled and educated students held the classes and taught the beginners the alphabet. However, the akhunds seldom tested knowledge of the beginners. Such students, who assisted the teachers were called "caliphs". The caliph did not only hold classes, but also had the competence to lead his disciples via falagga.

Curriculum. There was no unique curriculum at schools. The textbook written in syllables was considered as main textbook of schools with unknown dates of study. General methodology was not applied in all schools. However, according to general teaching method, first the names of letters, their spelling and later, the syllabizing of the words were taught. The children learnt to read the Holy Quran, only the method of calculation from arithmetic and geometry, calligraphy, Sadi Shirazi's works "Gulistan", "Bustan", Hafiz's "Divan" and so on at school. The purpose of the lesson was the memorization, not the perception. Each student was taught from a special book belonged to him. Some known books were read at the teacher's request after learning the Qur'an. Children who read the Qur'an throughly were considered to have completed their education.

The children of officials, also those who will represent the higher clergy in the future, needed more profound education. Books "Tanbihal-gafilin", "Jameyi-Abbasi", "Gulistan", "Nisabas-sabyan" and others are usually taught with this purpose. More difficult books such as "Tarihi-Mujam”, "Abvabul-jinan", "Tarihi-Wassaf", "Durreyi-Nadiri" and so on were taught after finishing these books. Such books were studied only by some educated teachers [Sardarniya Samad. 1380, 279]. Those who wanted to continue their education were taught morphology and syntax, calligraphy, literature, logic, law, arithmetic, astronomy and other subjects. Great importance was given to calligraphy. 
After mastering the Eastern literature, the students started new teaching by scholars and mojtaheds (clergyman competent to practice divine science or religious juriprudence). The mojtaheds organized teaching in their own house. Mojtaheds who remained in the memory of the people for many years in Tabriz are Haji Mirza Hasan agha, Mirza Abulhasan agha Angaji, Sheikh Abdulrahim Kalibari, Haji Sheikh Huseynali Vaiz, Mirza Alakbar Ahari, Mirza Lutfali agha, Martyr Saggatulislam, Hujjatulislam Haji Mirza Abdullah Mojtahidi and others.

A new lesson was held for four days a week and two days were devoted to the repetition of old materials. Friday was considered a day off. The study period, which covers four seasons could be extended depending on the child's mental development. There was no official vacation in summer, but sometimes the classes were suspended because most of the population moved to the country cottages. The students would take a day off when they finished one book and started a new one. A certain amount of money was given to the akhund to this end. This money was called "kitabi-avaziyya" [Meshkur Mehemmed Javad. 1302, 289].

Holidays and ceremonies at school. They used to go vacation for interesting reasons in the past. For example, the classes were delayed when woman in a nearby family gave birth. One of the family members addressed to the school administration, gave the akhund money and sugarloaf as a gift so that the students could be free from the classes on that day and pray for the mother and child. This ceremony was called "tabarraz" [Egbal Gasemipuya. 1377, 71]. Besides, school holidays were announced on Novruz and Ramadan holidays, in the month of Muharram, on the birthdays and on the day of death of saints.

The akhund distributed illustrated booklets to the children a few days before Novruz holiday. The children took a share (sugarloaf, fruit, cookie, etc.) to the akhund instead on last Tuesday before Novruz holiday. One of the events held at schools on the eve of the holiday was a poetry contest. The akhund divided the most knowledgeable students into two groups and one of them had to recite a poem beginning with the last letter of the word that the other said. In this way, they were encouraged to learn many poems by heart.

Various ceremonies were arranged at schools. A celebration was organized when the Surat al-Nas of Holy Quran was read up to Surat al-Ammi, i.e., when the teaching of 30 surats ended [Meshkur Muhammad Javad. 1302, 288]. Furthermore, the ceremony was held again when it came to Surat Yas. There was organized a special event on the occasion of the completion of Holy Quran. Parents gave money or gift to the teacher at that time. Besides, there was organized a reception for akhunds and classmates.

Teachers' work conditions and salary. Financial situation of school teachers was not so satisfactory. They did not most often receive individual salary from everyone. Parents of children from rich families gave gifts to the teachers after their children finished their education. The gift consisted mainly of Russian sugarloaf, a few boxes of Indian tea, a sprig of sugar plum, a few bottles of rose water, a box of sweets, a cloth and some money. About 5-10 gran money was taken from the students for the benefit of school [Egbal Gasemipuya. 1377, 56]. Home working teachers had a better way of living.

There were special schools for children of upper class. The children of the clergy and nobles did not go to school, but the teachers came to their house to teach them. Sometimes private room was allocated for teachers in the residences. The servant's child could not study in the same place with the landlord's child. The parents believed that their children could learn bad habits from lower-class children. That is why they kept them away from each other.

Girls' schools. There were very few girls' schools during the study period. Education was led by female teachers at female akhund schools as is known from the name. They were addressed with "mollabaj1", "shahbaji", "khanbaji" and other names by the people. 4-7-year-old girls were introduced small volume surats of Quran, taught rules of manners and etiquette and the alphabet orally. Exact time of admission to school is not specified, so anyone could start classes at any time. The teaching by female akhunds was considered a pre-school stage and organized mainly at the teacher's house.

Religious schools. There were hundreds of schools in Tabriz before new type of schools. Famous teachers had taught there. Seyid Hasan Zunuzi, Mirza Haji Muhammadhuseyn, Mirza Muhammadali Iravani, Molla Gasim Lang, Akhund Molla Kazim, Haji Mir Yahya Adibul-ulema Zunuzi and others who lived in the 80s of XIX century (1300 B.C.) can be cited [Meshkur Mehemmed Javad. 1302, 291-292].

Madrasahs provided wider education rather than schools. Madrasahs in Tabriz were first established during the Seljuk period. Later, the madrasahs were destroyed as a result of the Mongolian invasion and finally reopened in late 13th century [Onullahi. 1976, 32]. The madrasah was staffed by highly-educated teachers who taught the Eastern literature, history, geography, jurisprudence, mathematics and religious sciences. Their salaries, in general, maintenance of educational institutions were provided mainly through the income of the foundation's property. Some new type of madrasahs were called "schools."

Received 22 October 20Z1; Received in revised form 27 November 20Z1; Accepted 30 November 20Z1;

Available online 28 December 2021;

dai: 10.46291//CONTECHval5iss4ppl8-23 


\section{ICONTECH INTERNATIONAL JOURNAL OF SURVEYS, ENGINEERING, TECHNOLOGY}

Madrasahs imposed punishment methods on students for poor performance and indiscipline like in schools. Some measures were taken in this regard along with corporal punishment. Those who did not learn the lesson had to stand upside down and silent in the classroom and avoid contact with anyone. That student carried honours students' bags and paired their shoes. The most severe form of corporal punishment was to strike a student's leg with a stick into the falagga.

Religious madrasahs were set up after the spread of Islam religion in the East. Tabriz had a large number of madrasahs during the Middle Ages like leading cities of the Muslim East. The number of such educational institutions, popularly known as the "Tullab Madrasah" began to decline gradually in late 19th and early 20th centuries. Religious madrasahs such as Sadigiyya, Talibiyya, Haji Safarali, Hasan Padshah, Khaja Alasgar functioned during the study period.

New methodical schools. Haji Mirza Hasan Rushdiyye. The introduction of new method, i.e. the foundation of a new type of education and the modernization of the country as a whole was inevitable in the 70s of the XIX century. Cultural rapprochement with Europe and the reforms carried out in the country laid the foundation for this process. However, secular education was neglected because of overall backwardness and ignorance of the society. Teachers taught at home opposed new teaching method like some conservative clergymen, since they earnt a good living. This situation became more distinct in the first half of the 19th century. A number of secular schools were opened in Tabriz since 1970s and the number of enlightened intellectuals and supporters of new method education increased. One of them was Haji Mirza Hasan Rushdiyye.

Hasan Rushdiyye was from Tabriz and son of an influential family. His father Mollah Mehdi was well-known mojtahed of Tabriz. H. Rushdiyye got religious education for 11 years after completing his primary education and went to Najaf City to achieve his goal. Then he studied at a French school in Beirut city for 2 years and stayed in Istanbul for a while. He went to Egypt for studying at school opened by the English. He nevertheless did not like education in Egypt and returned to Beirut [Sardarniya Samad (1380), 282-283]. He became interested in European education during his student years and continued to adopt progressive ideas.

People's educationist H. Rushdiyye got acquainted with Rushdiyya (new method) schools during his stay in the Ottoman state and liked them very much. Teaching period in Rushdiyya schools, which means " maturity" in Arabic was 4 years. Secondary schools-rushdiyyas were opened in the Ottoman State since 1839 and expanded more during the Tanzimat movement. It was decided to open 25 Rushdiyya schools in the Ottoman territory in 1853 [Kaya Doganay Fatma, 108]. Rushdiyyas intended respectively for girls and boys were combined with primary classes in the first decades of the twentieth century. Thus, H. Rushdiyye decided to apply this method of teaching, which he saw in the Ottoman state in Azerbaijan.

H.Rushdiyye opened a new type of secular school-new method school for the first time for Muslims in 1883 in Yerevan, the historical city of Azerbaijan. His brother Haji Akhund helped him to organize the school [Sardarniya Samad (1380), 283]. This school was based on Ottoman rhetoric. The peculiarity of new teaching was that the alphabet was taught not by syllables, but by sounds. Nasraddin Shah visited that school during his visit to Russia in 1887 and asked H. Rushdiyye to open such a school in Tehran. He was about to entrust his brother with this place and leave for Iran. However, those who were close to Nasraddin Shah fear that the European morality applied by Mirza Hassan would be a threat to the government, so they protest against the opening of the school in Tehran. H. Rushdiyye is intercepted in Nakhchivan for this reason. He is not even allowed to return to Yerevan. He soon returned to Tabriz with the help of some kind people.

H. Rushdiyye opened the first new method schools in the whole Iran "Debirestani-Rushdiyye" and "MadraseyiRushdiyye" in Sheshgilan neighborhood of Tabriz in 1888. This step caused great joy of the people of Tabriz. Nobles and high-rank people also educated their children in this madrasah along with people from lower class. $\mathrm{H}$. Rushdiyye admitted children of a number of rich families to the madrasah for free. Exams were taken with the participation of famous people and everyone were surprised by the children's comprehensive knowledge. A decree was issued to cancel the madrasah next day of the exam and H. Rushdiyye was declared "an infidel" [Egbal Gasemipuya. 1377, 336]. He was forced to move to Mashhad, where he tried to open Rushdiyya school. However, the students of the religious school forced him to leave Mashhad because of their strong opposition to the new method.

Rushdiyye returned to Tabriz after six months and opened a new madrasah with 300 students. This time the students of Sadigiyya Madrasah closed his school. The opposition groups looted the madrasah's building and the administration faced serious threats. Rushdiyye had to live in Mashhad for several months again. He established a madrasah for the poor in the Charandab neighborhood of Tabriz on his return. 370 students studied there. The afore-mentioned madrasah was closed several times and replaced with a new one in the Nober neighborhood. According to the sources, the Rushdiyya madrasah started operating near the market for the fifth time. A selfless

Received 22 October 2021; Received in revised form 27 November 20ZI; Accepted 30 November 20Z|;

Available online 28 December 20Z1;

dai: 10.46291//CONTECHval5iss4ppl8-23 
teacher involved 470 students in this madrasah. This time, a group of ignorant people attacked and looted the building. One of the children felt down the stairs and died. Thus, the madrasah was closed and H. Rushdiyye went to Mashhad and established a disciplined school there [to Egbal Gasemipuya. 1377, 337]. There were many protesters against him in Mashhad. He returned to Tabriz and continued his activity there. The school he opened this time was located in the Sheshgilan neighborhood. H. Rushdiyye's brother Haji Akhund also opened a school in the mosque in Magsudiyya Square of Tabriz.

Rushdiyya madrasahs were of modern type. Subjects on linguistics (morphology, syntax), as well as Persian, Arabic and French languages were taught there along with the Quran and Sharia rules. Muhammadali Tarbiyet, Haji Vaiz, Sahhafzadeh (Parvarish), Huseyn Kamal Talibzadeh, Haji Mirza Ahmad Mudarris and other progressive-minded teachers worked at the Rushdiyya school. Abdulrahim Talibov donated 200 books on physics to the Rushdiyya madrasah in 1894 [Munika M. Ringer (1393), 176]. New method schools were not welcomed by some confessors for many innovations and they considered it contradictory to Islam.

Rushdiyya madrasah was defended by Aminaddovla (an aide to the crown). Aminaddovla was called to Tehran after Nasraddin Shah's death and thus the attacks against H. Rushdiyye increased. The intellectual established several schools in Tabriz at different times on the basis of new method school. Aminaddovla invited $\mathrm{H}$. Rushdiyye to Tehran to open a school. The school in Tabriz cancelled its activity after this incident. So, he set up a new methodical school in Tehran in 1897 and did important work in the field of culture and education in general.

H. Rushdiyye rendered exceptional services in the development of science and education in Tabriz. The people's educator behested to bury him near the school gates, so that students could trample down his grave every day. He wanted to be with his disciples even after his death in this way. He died in 1944 (H. 21 Azer 1323) at age of 95 in the city of Qom.

Textbooks. The opening of schools and writing new textbooks in northern Azerbaijan had a positive effect on the education system of Tabriz. One of the first and best source on the Azerbaijani language was the textbook "Vatan dili" (Language of motherland) by A.O. Chernyayevsky, the people's educator, the head of the Azerbaijan branch of the Gori Teachers' Seminary in 1882. [N.A. Tahirzadeh) 2015), 117]. This textbook is worked up in two parts. The second part of the book, co-authored by Safarali Valibeyov, was first published in Tbilisi in 1888. [A.O. Chernyayevsky (2007), 22-23]. H. Rushdiyye got acquainted with this textbook while working in Yerevan and published his textbook "Language of motherland" in 1894 [A.S. Abdullayev (1966), 238]. Examples of folklore, especially proverbs are widely used there. This textbook written in native language and taught the Arabic alphabet in the sovti (sound) method, had long been taught in madrasahs.

Other books were worked out in Tabriz on the eve of the publication of the textbook "Language of motherland". Mirza Sadiq ibn Molla Asadulla Tabrizi wrote a textbook entitled "Kitabcheyi-edebiyye" (Literature Booklet) in the city of Tabriz in 1893 [A.S. Abdullayev (1966), 227]. However, H. Rushdiyye's book was the first textbook written in native language.

The establishment of new method educational institutions caused him a great deal of tortures. The children were taught the alphabet by sound, i.e. new method, thus putting an end to illiteracy. The Rushdiyye Madrasah in Tabriz can be considered the culmination of the Iranian government's educational reforms.

\section{REFERENCES}

1. S.M Onullahi (1976) From the history of education and school of Tabriz (XIV-XV centuries) // News of the Academy of Sciences of the Azerbaijan SSR, History, philosophy and law series, Baku, No. 4

Egbal Gasemipuya (1377)

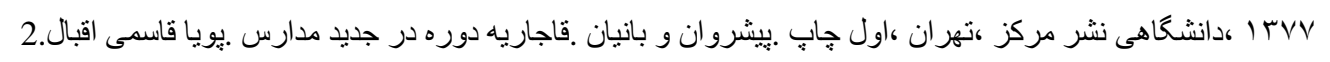

Sardarniya Samad (1380)

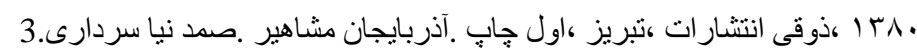

Meshkur Mehemmed Javad (1302)

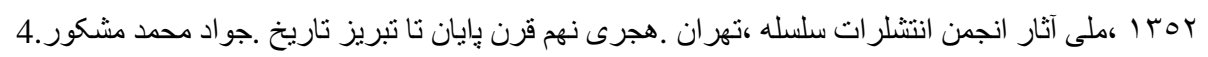

5. Kaya Doğanay Fatma. History Course in Rushdiyya Schools. p. 107-119, http://e-dergi.atauni.edu.tr/

Munika M.Ringer (1393)

Received 22 October 20Z1; Received in revised form 27 November 2021; Accepted 30 November Z0Z1;

Available online 28 December 2021;

dai: 10.46291//CONTECHvalSiss4ppl8-23 


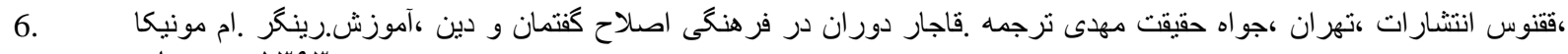

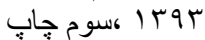

7. N.A. Tahirzade )2015) Essays on the history of Azerbaijani education and our first graduates. Baku: Nurlar Publishing House

8. A.O. Chernyayevsky (2007). Native language, part I; A.O., Chernyayevsky S.H.Valibeyov. Native language, part II. Compiler and transponeliterator, author of forewords, notes and comments, dictionaries and tables: Vugar Garadaghli. Baku

9. A.S. Abdullayev (1966). From the history of teaching the Azerbaijani language. Baku: Maarif Publishing House 